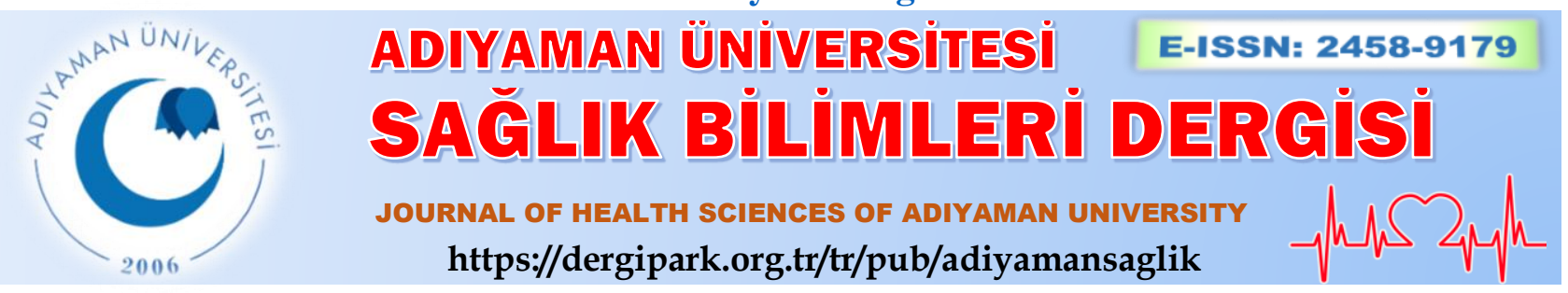

Özgün Araştırma/Research Article

\title{
Gebelikte üriner inkontinans ve yaşam kalitesi üzerine etkisi
}

\section{Urinary incontinence in pregnancy and impact on quality of life}

\author{
Ceylan GÜZEL İNAL ${ }^{1 @(D), ~ S e r m i n ~ T I M U R ~ T A S ̧ H A N ~}{ }^{2}$ \\ ${ }^{1}$ Şırnak Üniversitesi, Şırnak Meslek Yüksekokulu, 73000, Şırnak-Türkiye \\ 2̇̇nönü Üniversitesi, Hemşirelik Fakültesi, 44000, Malatya-Türkiye
}

Atıf gösterme/Cite this article as: Güzel İnal C, Timur Taşhan S. Gebelikte üriner inkontinans ve yaşam kalitesi üzerine etkisi. ADYÜ Sağllk Bilimleri Derg. 2020;6(2):150-160. doi:10.30569.adiyamansaglik.711065

Öz

Amaç: Araştırma gebelikte üriner inkotinans ve yaşam kalitesini etkileyen faktörleri belirlemek amaciyla yapılmıştır.

Gereç ve Yöntem: Araştırma kesitsel ve ilişki arayıcı olarak yapılmıştır. Araştırmanın örneklemini 523 gebe kadın oluşturmuştur. Verilerin toplanmasında katılımcı tanıtım formu, Bristol Kadın Alt Üriner Yol Semptomları Ölçeği (BKAÜYSÖ) ve Üriner İnkontinans Yaşam Kalitesi Ölçeği (ÜIYKÖ) kullanılmıştır.

Bulgular: Araştırmada gebelerin yarısından fazlası üriner inkontinans problemi yaşadığını ifade etmiştir. Araştırmada BKAÜYSÖ ile gebelik sayısı, gebelik haftası, küretaj olma, doğum şekli, konstipasyon, gebelikte sigara kullanımı arasında önemli ilişki saptanmıştır $(p<0,05)$. Ayrıca BKAÜYSÖ tüm alt boyutları ile ÜIYYKÖ tüm alt boyutları ve toplam puanı arasında negatif yönde önemli ilişki saptanmıştır $(p<0,05)$.

Sonuç: Araştırmada gebelikte üriner inkontinans probleminin yaygın olduğu ve gebelikte üriner inkontinans arttıkça yaşam kalitesinin azaldığı belirlenmiştir.

Anahtar Kelimeler: Gebelik; Üriner Inkontinans; Yaşam Kalitesi; Hemşirelik.

\begin{abstract}
Aim: The aim of this study was to investigate the factors affecting urinary incontinence and quality of life during pregnancy.

Materials and Methods: The study was performed cross-sectionally and correlational. The sample of the study was consisted of 523 pregnant women. The data were collected by using participant information form, the Bristol Female Lower Urinary Tract Symptoms (BFLUTS) and the Incontinence Quality of Life Scale (I-QOL).
\end{abstract}

Results: In the study, more than half of pregnant women stated that they had urinary incontinence problems. In this study, a significant relationship was found between BFLUTS and number of pregnancy, gestational week, curettage, type of delivery, constipation, smoking during pregnancy $(p<0,05)$. In addition, there was a negative correlation between all subscales of BFLUTS and all subscales of I-QOL and total score $(p<0,05)$.

Conclusion: In the study, it was determined that the problem of urinary incontinence was common during pregnancy and decreased quality of life as urinary incontinence increased during pregnancy.

Keywords: Pregnancy; Urinary Incontinence; Quality of Life; Nursing.

Yazışma Adresi/Address for Correspondence: Ceylan GÜZEL İNAL, Şırnak Üniversitesi, Şırnak Meslek Yüksekokulu, Yeni Mahalle Cizre Caddesi Mehmet Emin Acar Kampüsü, 73000, Şırnak-Türkiye, E-mail: cylngzl@ hotmail.com

Geliş Tarihi/Received:29.03.2020 Kabul Tarihi/Accepted:01.05.2020 $\quad$ Yayım Tarihi/Published online:30.08.2020 


\section{Giriş}

Üriner inkontinans (Üİ) kişinin yaşamını fiziksel, sosyal, psikolojik ve seksüel olarak etkileyebilen, utanma duygusuna ve kendine olan güvenin azalmasına neden olabilen, sosyal izolasyona yol açabilen ve ekonomik anlamda yük getirip yaşam kalitesini azaltan önemli bir sağlık problemidir. ${ }^{1}$ Üriner inkontinans prevelans1, Milsom ve arkadaşlarının 54 makaleyi incelendikleri bir meta analiz çalışmasında Amerika'da $\% 1,7-36,4^{2}$, Kumari ve arkadaşlarının Hindistan'da yürüttüğü bir çalışmada $\% 11,6^{3}$, Xie ve arkadaşlarının Çin'li kadınlarla yaptığ çalışmada $\% 31,2^{4}, \quad$ Mostafaei ve arkadaşlarının çalışmasında İran'lı kadınlarda $\% 57,7^{5}$ olarak hesaplanmıştır. Ülkemizde yapılan çalışmalarda ise kadınlarda üriner inkontinans prevelansı Akgün ve arkadaşlarının yaptığı çalışmada $\% 48,3^{6}$, Çiftçi ve Günay'ın çalışmasında \% $\% 36,6^{7}$, Özdemir ve arkadaşlarının çalışmasında \%22,6 olarak saptamıştır. ${ }^{8}$

Üriner inkotinansta pelvik taban yapısında ve kaslarında görülen bozukluklar, yaş, obezite, kronik konstipasyon, genetik yatkınlık, diabetes mellitus, kronik obstrüktif akciğer hastalığı, kadınlarda üretra boynunun kısalığı, hormonal durum (hipoöstrojenemi), doğum travması (sinir, kas, konnektif doku yaralanması), doğum sayısının fazla olması, iri bebek öyküsü, sezaryen, pelvik organ prolapsusu, jinekolojik-obstetrik cerrahi operasyonlar, çok sayıda düşük yapmış olma, servisit ve vajinit önemli risk faktörleridir. ${ }^{9-11}$ Ayrıca gebelikte kadın vücudunda meydana gelen hormonal ve mekanik değişiklikler pelvik desteğe zarar verebilmektedir. Gebelikte artan üreme hormonu ve relaksinin etkisiyle pelvik taban kaslarında değişiklik oluşmaktadır. Relaksin pelvik tabanda bulunan konnektif dokuyu doğuma hazırlamak üzere yumuşatmaktadır. Ayrıca gebelikte büyüyen uterusun karın içi basıncı arttırmas1 sonucu pelvik tabanda bulunan mesane gibi organlar aşağıya itilebilmekte ve burdaki kaslarının kasılmaları belirgin olarak azalabilmektedir. Pelvik kaslar üzerinde artan yük mesanenin basınç merkezini değiştirebilmekte, mesane ve üretra mobilitesi artabilmektedir. Gebelikte pelvik tabandaki tüm bu değişikliklerden dolayı üriner inkontinans gelişebilmektedir. ${ }^{12}$ Dünyanın çeşitli bölgelerinde yapılan çalışmalarda gebelikte $\dot{I U}$ prevalansı \%34-75 arasında saptanmıştır. ${ }^{13-15}$ Ülkemizde gebeler üzerinde yapılan iki çalışmada gebelikte üriner inkontinans prevelansı \%7 ile \%41,7 olarak bulunmuştur. ${ }^{16,17}$

Gebelikte meydana gelen fiziksel ve hormonal değişiklikler gebenin, fiziksel ve ruhsal yönden etkileyerek yaşam kalitesini de düşürebilmektedir., ${ }^{18}$ Gebelikte görülen bu problemlere inkontinansın da eşlik etmesi yaşam kalitesini olumsuz yönde daha fazla etkileyebilmektedir. ${ }^{18}$ Üriner inkontinans sonucu kötü koku, temizlik sorunu, cilt irritasyonu vb. problemler yaşayan gebeler tüm bunların sonucunda vücut imgesinde bozulma, utanma, anksiyete, depresyon ve sosyal izolasyona varan duygusal bozukluklar yaşabilmektedir. Yaşanan bu sorunlardan dolayı üriner inkontinanslı gebeler sıvı alımını kısitlama, emici ped kullanma, sürekli çamaşır değiştirme, tuvalet olmadığını bildiği yerlere gitmekten çekinme vb. yöntemler geliştirerek fiziksel ve sosyal yaşamlarına kısitlama koymakta ve toplumdaki diğer insanlarla bir araya gelmekten kaçınmaktadırlar. Bu nedenle gebelikte üriner inkontinans sıklığının, etkileyen faktörlerin ve yaşam kalitesi üzerine etkisinin belirlenmesi üriner inkontinans sorununun önemini ortaya koymakla birlikte sağllk personelinde farkındalık oluşturacaktır. ${ }^{1,18}$

$\mathrm{Bu}$ araştırma gebelikte üriner inkontinans ve yaşam kalitesi üzerine etkisinin belirlenmesi amacıyla yapılmıştır.

\section{Gereç ve Yöntem}

\section{Araştırmanın tipi}

Araştırma, kesitsel ve ilişki arayıcı araştırma olarak yapılmıştır.

\section{Araştırmanın evreni ve örneklemi}

Araştırmanın evrenini, araştırmanın yapıldığ 1 tarihlerde Diyarbakır Kadın Doğum ve Çocuk Hastalıkları Hastanesi kadın doğum poliklinikllerine başvuran gebelik haftası 30 hafta ve üzerinde olan 2560 gebe oluşturmuştur. Araştırmanın örneklem büyüklüğü $\quad \mathrm{G}^{*}$ Power $\quad 3.1 .9 .2$ programı 
kullanılarak hesaplanmıştır. Araştırmanın örneklemini, yapılan güç analizine göre 0,05 yanılg1 düzeyinde, \%95 güven aralığında ve 0,3 etki büyüklüğünde, evreni temsil etme gücüne sahip 523 gebe kadın oluşturmuştur. ${ }^{19}$ Araştırmada kadın doğum polikliniklerine başvuran ve araştırmaya alınma kriterlerini sağlayan gebeler, evrenden olasilıksız rastlantısal örnekleme yöntemiyle örneklem sayısına ulaşılıncaya kadar araştırmaya alınmıştır. Araştırmaya alınma kriterleri; tekil gebelik olma, tanı alınmış psikyatrik bir hastalığın olmaması ya da psikiyatrik ilaç kullanmama, geçmişte üriner inkontinans nedeniyle tıbbi veya cerrahi tedavi almamış olma, araştırmanın yürütüldüğü tarihte üriner sistem enfeksiyonu tanısı almamış olmadır.

\section{Veri toplama araçları}

Veriler haftanın rastgele günlerinde araştırmacı tarafından yüz yüze görüşme yöntemiyle araştırmacı tarafından toplanmıştır. Verilerin toplanmasında araştırmacı tarafından literatürden yararlanılarak oluşturulan katılımcı tanıtım formu, Bristol Kadın Alt Üriner Yol Semptomları Ölçeği (BKAÜYSÖ) ve Üriner İnkontinans Yaşam Kalitesi Ölçeği (ÜIYYKÖ) kullanılmıştır. Üriner inkontinans yaşam kalitesi ölçeği sadece üriner inkontinanslı gebelere uygulanmıştır.

\section{Katılımci tanitım formu}

Araştırmacı tarafından literatürden yararlanılarak geliştirilen bu form gebe kadınların, sosyo-demografik özelliklerini belirleyen (yaş, eğitim düzeyi, çalışma durumu, aylık gelir, gebelikten önceki kilo, boy) 6 soru, obstetrik özelliklerini belirleyen (gebelik sayısı, gebelik haftası, gebelikteki kilo, küretaj olma durumu, daha önce doğum yapma durumu, şekli, sayısı, ilk doğum yaşı, daha önce 24 saatten uzun doğum eylemi öyküsü, epizyotomi açılma durumu, daha önceki doğumlarda yardımcı doğum materyali kullanılma durumu) 12 soru, üriner inkontinans risk faktörlerine ilişkin özellikler belirleyen (gebelikte uzun süreli kabızlık şikayeti, gebelikte sigara kullanma durumu, gebelikte kafein içeren içecek içme durumu, gebelikten önce cinsel ilişki sırasında idrar kaçırma durumu, anne ya da kız kardeşte Üİ olma durumu, gebelikten önce ve gebelikte idrar kaçırma durumu, daha önce doğum sonu dönemde idrar kaçırma durumu) 13 soru olmak üzere toplam 31 sorudan oluşmaktadır.

\section{Bristol Kadın Alt Üriner Yol Semptomlart Ölçeği (BKÄ̈YSÖ)}

Ölçek Jackson ve arkadaşları tarafından 1996 yılında geliştirilmiştir. ${ }^{20}$ BFLUTS, alt üriner yol semptomlarını, cinsel yaşamı ve yaşam kalitesini belirlemek amaciyla geliştirilen çok boyutlu, 19 maddeden oluşan bir soru formudur. BFLUTS ölçeğinin Türkçe geçerlik ve güvenirliği Güngör ve Yalçın tarafından 2005 yılında yapılmıştır. ${ }^{21}$ Soru formundan en az 0 en fazla 71 puan alınabilmektedir. Soru formu 5 alt boyuttan oluşmaktadır. İlk üç boyutta depolama (1-4. sorular), idrar yapma, (5-7. sorular) ve inkontinansa (8-12. sorular) ilişkin sorular, dördüncü alt boyutta cinsel yaşama (13-14. soru) ve beşinci alt boyutta yaşam kalitesine (15-19. sorular) ilişkin sorular yer alır. Soru formunda maddeler 0 'dan 3'e (4. 13. 14. 17. ve 19. sorular) ya da 0 'dan 4'e (1-3., 5-12. ve 15. 16. sorular) kadar puanlanmaktadır. Ölçekten alınan skor yükseldikçe yaşam kalitesinin, cinsel yaşamın daha olumsuz yönde etkilendiğine ve semptomların daha şiddetli olduğuna işaret etmektedir. ${ }^{21}$ Ölçeğin ülkemizde yapılan geçerlik güvenirlik çalışmasında Cronbach Alpha katsayısı ölçek toplam için 0.66 saptanmıştır. ${ }^{21}$ Araştırmamızda ise Cronbach Alpha katsayısı ölçek toplam 0.77 olarak bulunmuştur.

Üriner Inkontinans Yaşam Kalitesi Ölçeği (ÜIYKÖ): Ölçek, 1996 y1lında Amerika'da Wagner ve arkadaşları tarafindan üriner inkontinans problemi yaşayanların yaşam kalitesini ölçmek amaciyla geliştirilmiştir. ${ }^{22}$ Ölçek Patrick ve arkadaşları tarafından 1999 yılında tekrar gözden geçirilerek soru sayısı 22'ye düşürülmüştür. ${ }^{23}$ Ülkemizde, ÜİHYKÖ’nin geçerlilik ve güvenirliği 2010 yılında Eyigor ve arkadaşları tarafından yapılmıştır. $^{24}$ ÜIYKÖ üç alt boyuttan oluşmaktadır. Bunlar, Davranışların sınırlandırılması (DS), Psikososyal etkilenme $(\mathrm{PE})$ ve Sosyal izolasyondur (SI). ÜIYYKÖ'nde, bütün sorular beşli likert tiptedir. Ölçeğin alt boyut puanları ve toplam puanı hesaplanırken her bir boyuttaki 
soruların toplam puanı alınır. Ölçek toplam puanın alabileceği maksimum puan 110 iken DS alt boyutunun 40, PE alt boyutunun 45, SI alt boyutunun ise 25 puandır. Ölçekten alınan puanın düşük olması daha kötü yaşam kalitesini gösterirken, yüksek olması ise yaşam kalitesinin daha iyi olduğunu gösterir. Ölçek toplam puanı ve alt boyut puanlarını hesaplamada alınan puanın daha iyi anlaşılması amacıyla dönüşümler kullanılarak (ÜIYYKÖ toplam puan $=\mathrm{Xi} / 110 \times 100$, DS:Skor $=\mathrm{Xi} / 40 \times 100, \quad$ PE:Skor $=\mathrm{Xi} / 45 \times 100$, Sİ:Skor $=X i / 25 \times 100$ ) 0-100'lük puanlama sistemine uyarlanmıştır. ${ }^{24}$ Türkçeye uyarlanan ölçeğin toplam Cronbach Alfa katsayısı 0.91 bulunmuştur. ${ }^{24}$ Araştırmamızda ise Cronbach alfa katsayısı 0.94 olarak saptanmıştır.

\section{Verilerin analizi}

Verilerin değerlendirilmesi Statistical Package for the Social Sciences (SPSS) 20.0 paket programı kullanılarak bilgisayar ortamında gerçekleştirilmiştir. Verilerin analizinde öncelikle normal dağılım gösterip göstermediği Shapiro-Wilk testi ile incelenmiştir. Analiz sonuçlarına göre verilerin normal dağılıma uyduğu saptanmıştır. Araştırmada tanımlayıcı istatistikler; aritmetik ortalama, standart sapma, sayı, yüzde, minimum ve maksimum değerler, iki grubun ortalamaları arasındaki farkın istatistiksel olarak anlamlı olup olmadığını anlamak için bağımsız gruplarda $t$ testi, üç ve daha fazla bağımsız ortalama arasındaki farkın anlamlılığının değerlendirilmesinde ANOVA, veriler arasındaki ilişkinin değerlendirilmesinde Pearson Korelasyon Analizi ve çoklu karşılaştırma testlerinden olan Tukey HSD kullanılmıştır. Sonuçlar \%95'lik güven aralığında anlamlılık $p<0,05$ düzeyinde değerlendirilmiştir.

\section{Araştırmanın etik boyutu}

Araştırma Helsinki İlkeleri Deklerasyonu'na uygun olarak hazırlanmış ve yapılabilmesi için ilgili üniversitenin Sağlık Bilimleri Girişimsel Olmayan Klinik Araştırmalar Etik Kurulu'ndan onay (2017/13-20) ve araştırmanın yürütüldüğü kurumdan yazılı izin alınmıştır. Ayrıca araştırmaya katılan tüm gebelere bilgilendirilmiş onam formu imzalatılmıştır.

\section{Bulgular}

Araştırmada gebelerin \%64,2'sinin 21-34 yaş aralığında olduğu ve \%35,6'sının okuryazar olmadığı saptanmıştır. Gebeler \%91,2 oranla çalışmadığını ve \%49,9 oranla gelirlerinin giderlerinden az olduğunu belirtmiştir. Araştırmada gebelerin \%52,6'sının gebelikte idrar kaçırdığ 1 ve en fazla $\% 31,5$ oranla günde bir kez idrar kaçırdığ 1 saptanmıştır. Gebelerin \%14,5'i gebelikten önce de idrar kaçırdığını ifade etmiştir. Ayrıca gebelerin \%2,9'u gebelikten önce cinsel ilișki sırasında idrar kaçırdığını ve \%55'i doğum sonu dönemde idrar kaçırma öyküsü olduğunu belirtmiştir (Tablo 1).

Araştırmada gebelerin BKAÜYSÖ alt boyutlarına göre puan ortalamaları, depolama $8,55 \pm 3,20$, idrar yapma $1,30 \pm 1,95$, inkontinans $3,68 \pm 4,35$, cinsel yaşam $0,41 \pm 1,21$, yaşam kalitesi $4,89 \pm 5,21$ olarak bulunmuştur. Ölçeğin toplam puan ortalaması ise $18,77 \pm 12,26$ 'dir (Tablo 2).

Gebelerin ÜIYKÖ alt boyutlarına göre puan ortalamaları, davranışların sınırlandırılması $55,63 \pm 19,69$, psikososyal etkilenme $73,04 \pm 23,75$, sosyal izolasyon $60,27 \pm 21,55$ olarak bulunmuştur. Ölçeğin toplam puan ortalamas1 ise $63,64 \pm 20,93$ olarak bulunmuştur (Tablo 2).

Araştırmada gebelerin, gebelik sayısı ortalamasının 3,79 $\pm 2,87$ ve $\% 73,4$ 'ünün 36 . hafta ve üzerinde gebe olduğu saptanmıştır. Gebelerin \%59,6'sı ilk doğum yaşının 19-25 arasında olduğunu belirtmiştir. Gebelerin $\% 14,3$ 'ü daha önce küretaj olduğunu, $\% 61,2$ 'si daha önce vajinal doğum yaptığını ve \%50,3'ü ise 3 ve üzerinde vajinal doğum yaptığını ifade etmiştir. Gebelerin \%35'i 24 saatten uzun süren doğum eylemi öyküsünün olduğunu, \%59,3'ü epizyotomi uygulandığını ve $\% 10,3$ '̈̈ daha önce enstrümental doğum yaptığını belirtmiştir (Tablo 3 ).

Araştırmada gebelik sayısı dört ve üzeri olan gebelerde BKAÜYSÖ puan ortalamasının istatistiksel olarak anlamlı düzeyde daha yüksek olduğu saptanmıştır $(p<0.05)$. Ayrıca çalışmada gebelik haftası 36 
hafta ve üzerinde olan gebelerin ve ilk doğum yaşı 18 yaş ve altında olan gebelerin BKAÜYSÖ puan ortalamalarının istatistiksel anlamlı olarak daha yüksek olduğu görülmüştür $(p<0.05)$. Daha önce küretaj olan gebelerin de statistiksel anlamlı olarak daha yüksek BKAÜYSÖ puan ortalamasına sahip oldukları saptanmıştır $(p<0.001)$. Araştırmada daha önce hem vajinal hem de sezeryanla doğum yapmış olan gebelerin BKAÜYSÖ puan ortalamasının istatistiksel olarak anlamlı ölçüde daha yüksek olduğu görülmüştür $(p<0.001)$. Vajinal doğum sayısı üç ve üzerinde olan gebelerin istatistiksel anlamlı olarak daha yüksek BKAÜYSÖ puan ortalamasına sahip oldukları saptanmıştır ( $p<0.001)$. Araştırmada 24 saatten uzun süren doğum deneyimi olan gebelerin BKAÜYSÖ puan ortamasının istatistiksel olarak anlamlı düzeyde daha yüksek olduğu saptanmıştır $(p<0.001)$. Çalışmada daha önce epizyotomi uygulamas1 yapılan gebelerin BKAÜYSÖ puan ortalamasının yapılmayanlara göre istatistiksel anlamlı olarak daha yüksek olduğu saptanmıştır $(p<0.001)$. Ayrıca daha önce enstrümental doğum yapan gebelerin istatistiksel olarak anlamlı ölçüde daha yüksek BKAÜYSÖ puan ortalamasına sahip oldukları saptanmıştır $(p<0.001)$ (Tablo 3).

Tablo 1. Gebelerin sosyo-demografik ve üriner inkontinansa ilişkin özelliklerinin dağılımı.

\begin{tabular}{|c|c|c|}
\hline Sosyo-Demografik ve Üİ'ye İlişkin Özellikler & 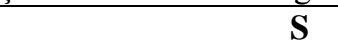 & $\%$ \\
\hline \multicolumn{3}{|l|}{ Yaș } \\
\hline$\leq 20$ & 69 & 13,2 \\
\hline $21-34$ & 336 & 64,2 \\
\hline$\geq 35$ & 118 & 22,6 \\
\hline \multicolumn{3}{|l|}{ Eğitim Düzeyi } \\
\hline Okur-yazar değil & 186 & 35,6 \\
\hline İlköğretim & 198 & 37,8 \\
\hline Lise ve üzeri & 139 & 26,6 \\
\hline \multicolumn{3}{|l|}{ Çalıșma Durumu } \\
\hline Çalışıyor & 46 & 8,8 \\
\hline Çalışmiyor & 477 & 91,2 \\
\hline \multicolumn{3}{|l|}{ Aylık Gelir Düzeyi } \\
\hline Gelirim giderimden az & 261 & 49,9 \\
\hline Gelirim giderime eşit & 220 & 42,1 \\
\hline Gelirim giderimden çok & 42 & 8,0 \\
\hline \multicolumn{3}{|l|}{ Gebelikte İdrar Kaçırma } \\
\hline Evet & 275 & 52,6 \\
\hline Hayır & 248 & 47,4 \\
\hline \multicolumn{3}{|l|}{ "Gebelikte İdrar Kaçırma Sıklığı (s=275) } \\
\hline Haftada 1 veya daha az & 66 & 24,0 \\
\hline Haftada $2-3 \mathrm{kez}$ & 78 & 28,4 \\
\hline Günde $1 \mathrm{kez}$ & 86 & 31,3 \\
\hline Günde birkaç kez & 45 & 16,3 \\
\hline \multicolumn{3}{|l|}{ Gebelikten Önce İdrar Kaçırma } \\
\hline Evet & 76 & 14,5 \\
\hline Hayır & 447 & 85,5 \\
\hline \multicolumn{3}{|l|}{ Gebelikten Önce Cinsel İliski Sırasında İdrar Kacırma } \\
\hline Evet & 15 & 2,9 \\
\hline Hayır & 508 & 97,1 \\
\hline \multicolumn{3}{|l|}{ ***ăum Sonu Dönemde İdrar Kaçırma Öyküsü (s=369) } \\
\hline Evet & 203 & 55,0 \\
\hline Hayır & 166 & 45,0 \\
\hline \multicolumn{3}{|c|}{ * Sadece gebeliğinde idrar kaçıran gebeler cevaplamıştır.** Sadece daha önce doğum yapanlar cevaplandırmıştır. \% Yüzde } \\
\hline Araştırmada gebelerin $\quad \% 46$ 's1 & \multirow{6}{*}{\multicolumn{2}{|c|}{$\begin{array}{l}\text { saptanmıştır. Araştırmada gebelerin \%23,7'si } \\
\text { gebelikten önce ve } \% 20,1 \text { 'i gebeliklerinde } \\
\text { sigara kullandığını ifade etmiştir. Gebelerin } \\
\% 26,2 \text { 'si gebelikten önce ve } \% 23,7 \text { 'si } \\
\text { gebeliklerinde kafein içeren içecek tükettiğini } \\
\text { belirtmiştir. Ayrıca gebelerin } \% 21,2 \text { 'si anne }\end{array}$}} \\
\hline gebeliklerinde uzun süreli konstipasyon & & \\
\hline yaşadığını belirtmiştir. Gebelerin \%75,9'unun & & \\
\hline gebelikten önceki, beden kitle indeksinin 25 & & \\
\hline ve üzerinde olduğu ve gebelerin \%75'inin & & \\
\hline gebelikte 11 ile 17 arasında kilo aldiğ 1 & & \\
\hline
\end{tabular}


veya kız kardeşinde Üİ olduğunu ifade etmiştir (Tablo 3).

Çalışmada gebelikte konstipasyon yaşayan gebelerin BKAÜYSÖ puan ortlamasinın istatistiksel olarak anlamlı düzeyde daha yüksek olduğu saptanmıştır $\quad(p<0.001)$. Gebelikten önceki beden kitle indeksi 25 ve üzerinde olan gebelerin ve gebelikte $18 \mathrm{~kg}$ ve üzerinde kilo alan gebelerin istatistiksel anlamlı olarak daha yüksek BKAÜYSÖ puan ortalamasına sahip oldukları görülmüştür $(p<0.001)$. Gebelikte sigara kullanan gebelerin BKAÜYSÖ puan ortalamalarının istatistiksel anlamlı olarak daha yüksek olduğu bulunmuştur $(p<0,05)$. Ayrıca gebelikte kafein içeren içecek tüketen gebelerin tüketmeyenlere oranla istatistiksel olarak anlamlı düzeyde daha yüksek BKAÜYSÖ puan ortalamalarına sahip oldukları saptanmıştır $(p<0.05)$ (Tablo $3)$.

Tablo 2. Gebelerin BKAÜYSÖ ve ÜİYKÖ puan ortalamalarının dağılımı.

\begin{tabular}{lc}
\hline BKAÜYSÖ $(\mathbf{S = 5 2 3})$ & $\mathbf{X} \pm \mathbf{S S}$ \\
\hline Depolama Alt Boyutu & $8,55 \pm 3,20$ \\
\hline İdrar Yapma Alt Boyutu & $1,30 \pm 1,95$ \\
\hline İnkontinans Alt Boyutu & $3,68 \pm 4,35$ \\
\hline Cinsel Yaşam Alt Boyutu & $0,41 \pm 1,21$ \\
\hline Yaşam Kalitesi Alt Boyutu & $4,89 \pm 5,21$ \\
\hline Toplam & $18,77 \pm 12,26$ \\
\hline *ÜİYKÖ (S=275) & $55,63 \pm 19,69$ \\
\hline Davranışların Sınırlandırılması (DS) Alt Boyutu & $73,04 \pm 23,75$ \\
\hline Psikososyal Etkilenme (PE) Alt Boyutu & $60,27 \pm 21,55$ \\
\hline Sosyal İzolasyon (Sİ) Alt Boyutu & $63,64 \pm 20,93$ \\
\hline Toplam &
\end{tabular}

Gebelerin BKAÜYSÖ puan ortalamaları ile ÜIYKKÖ puan ortalamaları arasındaki ilişki Tablo 4'te verilmiştir. Buna göre; BKAÜYSÖ depolama alt boyutu ile ÜIYYKÖ davranışların sinırlandırılması alt boyutu arasında yüksek düzeyde negatif yönde anlamlı ilişki saptanırken, ÜIYYKÖ psikososyal etkilenme ve sosyal izolasyon alt boyutları ve ÜIYYKÖ toplam puan ortalaması arasında orta düzeyde negatif yönde anlamlı ilişki saptanmıştır $(p<0,001)$.

BKAÜYSÖ idrar yapma alt boyutu ile ÜIYKÖ davranışların sınırlandırılması ve sosyal izolasyon alt boyutları ve ÜIYKÖ toplam puan ortalaması arasında çok zayıf düzeyde negatif yönde anlamlı ilişki bulunmuşken, ÜIYKÖ̈ psikososyal etkilenme alt boyutu arasında negatif yönde zayif düzeyde anlamlı ilişki bulunmuştur $(p<0,05)$.

BKAÜYSÖ inkontinans alt boyutu ile ÜIYYKÖ davranışların sınırlandırılması alt boyutu arasında yüksek düzeyde negatif yönde anlamlı ilişki saptanmıştır. Ayrıca BKAÜYSÖ inkontinans alt boyutu ÜIYKÖ psikososyal etkilenme ve sosyal izolasyon alt boyutları ve ÜIYKÖ toplam puan ortalaması arasında çok yüksek düzeyde negatif yönde anlamlı ilişki bulunmuştur $(p<0,001)$.

BKAÜYSÖ cinsel yaşam alt boyutu ile ÜIYKÖ tüm alt boyutları ve ÜIYKÖ toplam puan ortalaması arasında yüksek düzeyde negatif yönde anlamlı ilişki saptanmıştır $(p<0,001)$.

BKAÜYSÖ yaşam kalitesi alt boyutu ile ÜIYKKÖ davranıșların sınırlandırılması alt boyutu ve ÜIYYKÖ toplam puan ortalaması arasında çok yüksek düzeyde negatif yönde anlamlı ilişki saptanırken, BKAÜYSÖ yaşam kalitesi alt boyutu ile ÜIYKKÖ psikososyal etkilenme ve sosyal izolasyon alt boyutları arasında yüksek düzeyde negatif yönde anlamlı ilişki saptanmıştır $(p<0,001)$.

\section{Tartışma}

Araştırmada gebelerin yarıdan fazlası gebeliklerinde Üİ problem yaşadıklarını ifade etmiştir. Farklı kültürlerde gebelikte ÜI'a ilişskin yapılan çalışmalarda Üİ prevelansı \%34-75 arasında değişmektedir. ${ }^{13,14,25}$ Türkiye'de yapılan çalışmalarda bu oran \%21-42 arasında saptanmıştır. ${ }^{16,17,26-28}$ 
Tablo 3: Gebelerin BKAÜYSÖ puan ortalamasının Üİ risk faktörlerine göre dağılımı ( $\mathrm{S}=523)$

\begin{tabular}{ccccc}
\hline ÜI Risk Faktörlerine İlişkin Özellikler & Sayı & $\%$ & BKAÜYSÖ & İstatistiksel Test ve \\
& & & Anlamlıs &
\end{tabular}

\begin{tabular}{|c|c|c|c|c|}
\hline \multicolumn{5}{|l|}{ * Gebelik Sayısı } \\
\hline 1 & 134 & 25,6 & $11,75 \pm 8,14$ & \multirow{4}{*}{$\begin{array}{c}\mathrm{F}=\mathbf{5 0 , 5 7 1} \\
p=0,001\end{array}$} \\
\hline 2 & 86 & 16,4 & $14,44 \pm 9,40$ & \\
\hline 3 & 74 & 14,2 & $16,85 \pm 10,94$ & \\
\hline 4 ve üzeri & 229 & 43,8 & $25,12 \pm 12,5$ & \\
\hline \multicolumn{5}{|l|}{ ** Gebelik Haftası } \\
\hline $35 \leq$ & 139 & 26,6 & $16,16 \pm 12,16$ & \multirow{2}{*}{$\begin{array}{l}t=2,952 \\
p=0,003\end{array}$} \\
\hline $36 \geq$ & 384 & 73,4 & $19,71 \pm 12,17$ & \\
\hline \multicolumn{5}{|l|}{ 阝 İlk Doğum Yaşı } \\
\hline$\leq 18$ & 118 & 32,0 & $24,53 \pm 13,44$ & \multirow{3}{*}{$\begin{array}{l}\mathrm{F}=24,642 \\
p=0,001\end{array}$} \\
\hline $19-25$ & 220 & 59,6 & $19,83 \pm 12,27$ & \\
\hline$\geq 26$ & 31 & 8,4 & $19,32 \pm 10,03$ & \\
\hline \multicolumn{5}{|l|}{ Küretaj Olma } \\
\hline Evet & 75 & 14,3 & $23,88 \pm 13,91$ & \multirow{2}{*}{$\begin{array}{r}\mathrm{t}=\mathbf{3 , 5 3 2} \\
p=0,001\end{array}$} \\
\hline Hayır & 448 & 85,7 & $17,91 \pm 11,78$ & \\
\hline \multicolumn{5}{|c|}{${ }^{\beta}$ Doğum Şekli (s = 369) } \\
\hline Vajinal & 226 & 61,2 & $21,61 \pm 13,01$ & \multirow{3}{*}{$\begin{array}{l}\mathrm{F}=7,789 \\
p=0,001\end{array}$} \\
\hline Sezeryan & 57 & 15,4 & $15,81 \pm 10,34$ & \\
\hline Vajinal+Sezeryan & 86 & 23,4 & $24,08 \pm 12,11$ & \\
\hline \multicolumn{5}{|c|}{ Vajinal Doğum Yapma Sayısı (s = 312) } \\
\hline 1 & 80 & 25,7 & $15,20 \pm 9,77$ & \multirow{3}{*}{$\begin{array}{l}\mathrm{F}=28,794 \\
p=0,001\end{array}$} \\
\hline 2 & 75 & 24,0 & $19,89 \pm 3,03$ & \\
\hline$\geq 3$ & 157 & 50,3 & $27,05 \pm 12,09$ & \\
\hline
\end{tabular}

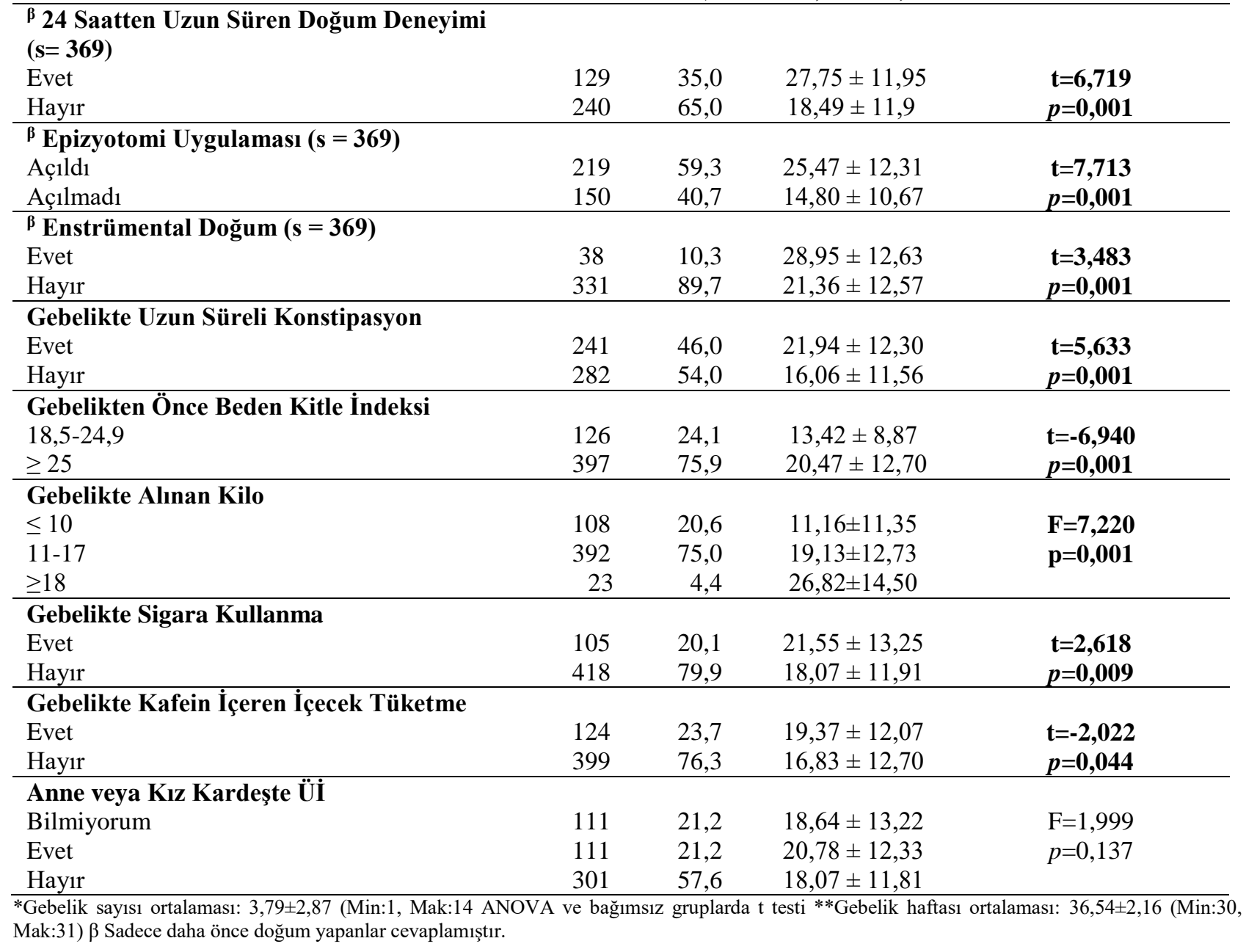


Tablo 4. Gebelerin BKAÜYSÖ puan ortalamaları ile ÜIYKÖ puan ortalamaları arasındaki ilişsi ( $\mathrm{S}=275)$.

\begin{tabular}{|c|c|c|c|c|c|c|c|c|}
\hline \multirow{3}{*}{$\begin{array}{l}\text { BKAÜYSÖ Alt } \\
\text { Boyutları }\end{array}$} & \multicolumn{6}{|c|}{ ÜİYKÖ Alt Boyutları } & \multirow{2}{*}{\multicolumn{2}{|c|}{$\begin{array}{c}\text { ÜİYKÖ } \\
\text { Toplam Puanı }\end{array}$}} \\
\hline & \multicolumn{2}{|c|}{$\begin{array}{l}\text { Davranışaların } \\
\text { Sınırlandırılması }\end{array}$} & \multicolumn{2}{|c|}{$\begin{array}{c}\text { Psikososyal } \\
\text { Etkilenme }\end{array}$} & \multicolumn{2}{|c|}{$\begin{array}{l}\text { Sosyal } \\
\text { İzolasyon }\end{array}$} & & \\
\hline & $\mathbf{r}$ & $p$ & $\mathbf{r}$ & $p$ & $\mathbf{r}$ & $p$ & $\mathbf{r}$ & $p$ \\
\hline Depolama &,- 675 & ,001 &,- 528 & ,001 & ,559 & ,001 &,- 593 & ,001 \\
\hline İdrar Yapma &,- 119 & ,048 &,- 249 & ,001 & , 186 & ,002 &,- 199 & ,001 \\
\hline İnkontinans &,- 791 & ,001 &,- 823 & ,001 & ,807 & ,001 &,- 835 & ,001 \\
\hline Cinsel Yaşam &,- 683 & ,001 &,- 774 & ,001 & ,728 & ,001 &,- 759 & ,001 \\
\hline Yaşam Kalitesi &,- 834 & ,001 &,- 755 & ,001 &,- 773 & ,001 &,- 807 & ,001 \\
\hline
\end{tabular}

Araştırma bulgusu farklı kültürlerde yapılan çalışma bulgularıyla benzerlik gösterirken, Türkiye'de yapılan çalışma bulgularından farkl1lık göstermektedir. Farklılı̆ı̆ nedeninin gebelerde Üİ tanısının belirlenme şeklinden kaynaklanmış olabileceği düşünülmektedir. Nitekim araştırmada Üi tanısı gebelerin beyanlarına göre konulmuştur.

Araştırmada gebelik sayısı ve haftasının artmasiyla alt üriner yol semptomlarının da $\operatorname{arttığ1}$ saptanmıştır $\quad(p<0,001)$. Yapılan çalışmalar incelendiğinde araştırma bulgusunu destekleyecek şekilde gebelik sayıs1 $^{7,29}$ ve gebelik haftasi ${ }^{27,30,31}$ arttıkça alt üriner yol semptomlarının da arttığı saptanmıştır.

Çalışmada ilk doğum yaşı 18 yaş ve altında olan gebelerde alt üriner yol semptomlarının daha fazla görüldüğü saptanmıştır $(p<0,001)$. Literatürde ilk doğum yaşı ve Üİ arasında ilişki bulan çalışmaların ${ }^{32,33}$ yanı sıra ilişki bulmayan çalışmalar ${ }^{34}$ da mevcuttur.

Araştırmada küretaj olma ve vajinal doğum yapma ile alt üriner yol semptomları arasında önemli ilişki olduğu saptanmıştır $(p<0,001)$. Brown ve arkadaşlarının çalışmasında önceki düşük ve küretajların gebelikte Üİ görülme sıklığını artırdığı saptanmıştır. ${ }^{35}$ Literatürde vajinal doğum ile Üİ arasında ilişki bulan birçok çalışma mevcuttur. ${ }^{9,25,27,28}$ Araştırma bulgusu literatür ile benzerlik göstermektedir.

Çalışmada vajinal doğum sayısının artmasiyla beraber alt üriner yol semptomlarının da arttığı saptanmıştır $(p<0,001)$. Kök ve arkadaşlarının çalışmasında da Üİ yaşayan gebelerin büyük bir kısmının daha önce iki veya daha fazla sayıda vajianal doğum yaptı ğı saptanmıştır. ${ }^{28}$

Araştırmada 24 saatten uzun süren doğum öyküsü olan gebelerde BKAÜYSÖ puan ortalamasının daha yüksek olduğu bulunmuştur $(p<0,001)$. Bilgili ve arkadaşları yaptıkları çalışmada 24 saatten uzun süren doğum eylemi öyküsünün Üİ görülme sıklığını artırdığını saptamıştır. ${ }^{36}$ Araştırma bulgusu Bilgili ve arkadaşlarının çalışma bulgusu ile benzerlik göstermektedir.

Epizyotomi perine travmasina neden olabilmekte ve perine travması sonucu Üİ gelişebilmektedir. ${ }^{18}$ Çalışamada epizyotomi öyküsü ile alt üriner yol semptomları arasında önemli iliş̧ki olduğu saptanmıştır $(p<0,001)$. Bekele ve arkadaşları araştırmalarında, çalışma sonucuna benzer olarak epizyotomi ile Üİ arasında önemli ilişski saptamıştır. ${ }^{34}$

Araştırmada enstrümetal doğum öyküsü ile BKÜYSÖ puan ortalaması arasında önemli iliş̧ki saptanmıştır $(p<0,001)$. Baydock ve arkadaşlarının yaptığı çalışmada forseps kullanımının Üİ riskini iki kat arttırdığı saptanmıştır. ${ }^{37}$ Araştırma bulgusu Baydock ve arkadaşlarının bulgusuna paraleldir.

Araştırmada gebeliğinde uzun süreli konstipasyon şikâyeti olan gebelerde BKAƯYSÖ puan ortalamasının daha yüksek olduğu dolayısıyla bu gebelerde alt üriner yol semptomlarının daha fazla görüldüğü saptanmıştır $(p<0,001)$. Literatürde araştırma bulgusunu destekleyen çalışmalar mevcuttur. ${ }^{14,16,27,29,34,38}$

BKİ'deki artış sonucunda, mesane üzerindeki artan karın içi basınca ve aşırı 
üretral mobiliteye bağlı olarak ÜI görülebilmektedir. ${ }^{39}$ Çalışmada gebelikten önceki BKİ 25 ve üzerinde olan gebelerin ve gebeliğinde $18 \mathrm{~kg}$ ve üzerinde kilo alan gebelerin BKAÜYSÖ puan ortalaması BKİ normal sinırlarda olan gebelerin puan ortalamasindan daha yüksektir $(p<0,001)$. Literatürde artan BKİ'nin Üİ için önemli bir risk faktörü olduğunu gösteren çalışmalar mevcuttur. $^{31,34,40}$

Sigara kullananlarda oluşan kronik öksürük karın içi basıncın artmasına neden olarak idrar kaçırmayı kolaylaştırmakta ve sigarada bulunan nikotin, mesane kontraksiyonlarını artırarak Üİ riskini artırabilmektedir. ${ }^{39}$ Araştırmamızda gebelikte sigara kullanma ile beraber alt üriner yol semptomlarının arttığı saptamıştır $(p<0,05)$. Literatürde araştırma bulgusunu destekleyecek şekilde sigara kullanmanın üriner inkontinans görülme sıklığını arttırdığını saptayan çalışmalar mevcuttur. ${ }^{14,29,31}$

Kafein detrüsör kasını etkileyerek diüretik etki göstermektedir. ${ }^{39}$ Araştırmada gebelikte kafein içeren içecek tüketimi ile alt üriner yol semptomları arasında önemli ilişki olduğu saptanmıştır $\quad(p<0,05)$. Martin's ve arkadaşlarının yaptığı çalışmada günde iki fincan üstünde kahve içen gebelerde 1,7 kat daha fazla Üİ görüldüğ̈̈ saptanmıştır. ${ }^{29}$ Bulgumuz Martin's ve arkadaşlarının bulgusu ile benzerlik göstermektedir.

Araştırmamızda anne veya kız kardeşte Üİ öyküsü ile alt üriner yol semptomları arasında önemli ilişki olduğu saptanmıştır $(p>0,05)$. Literatürde Üİ ile anne veya kız kardeşte ÜI öyküsü ${ }^{29,38}$ arasında ilişki saptamayan çalışmaların yanısıra Üİ ile anne veya kız kardeşte Üİ öyküsü arasında önemli ilişki bulan çalışmalar da yer almaktadır. ${ }^{16,28,33}$

Üİ problemi yaşayan gebeler, idrar kaçırma durumunun dişarıdan fark edilebileceğini düşünerek kendilerini kusurlu hissetmekte, daha az çekici olduklarını ve cinsel güçlerinin azaldığını düşünmektedirler. $\mathrm{Bu}$ nedenle depresyona ve sosyal izolasyona daha yatkındırlar. ${ }^{1}$ Çalışmamızda alt üriner yol semptomlarının artmasıyla beraber yaşam kalitesinin davranışların sınırlandırılması, psikososyal etkilenme ve sosyal izolasyon alt boyutlarında azalma olduğu saptanmıştır $(p<0,001)$. Oh ve $\mathrm{Ku}$ 'nun 28 kadınla yaptığ 1 çalışmada BKAÜYSÖ inkontinans alt boyutu ile ÜIYKÖ psikososyal etkilenme ve sosyal izolasyon alt boyutları ve toplam puan ortalaması arasında ve BKAÜYSÖ yaşam kalitesi alt boyutu ile ÜIYKÖ toplam puanı ve tüm alt boyutları arasında negatif yönde önemli ilişki saptanmıştır. ${ }^{41}$ Benzer şekilde Dağdeviren ve arkadaşlarının ${ }^{17}$ ve Kök ve arkadaşlarının $^{28}$ çalışmasında da üriner inkontinans problemi artıkça yaşam kalitesinin olumsuz yönde etkilendiği saptanmıştır. Bulgumuz Oh ve Ku'nun, Dağdeviren ve arkadaşlarının ve Kök ve arkadaşlarının çalışma bulgusu ile benzerlik göstermektedir.

Çalışmada literatüre benzer olarak gebelerin yarısından fazlasinın üriner inkontinans problemi yaşadığı ve üriner inkontinans problemi olan gebelerin daha çok davranışlarını sınırlandırma eğilimde olduğu, psikososyal yönden etkilendikleri ve sosyal izolasyona yatkın oldukları belirlenmiştir.

\section{Araștırmanın Kısıtlılıkları}

Araştırmada örneklemin olasılıksız örnekleme yöntemiyle seçilmiş olması ve sonucun sadece bu çalışma grubuna genellenmesi araştırmanın sınırlılığını oluşturmaktadır.

\section{Sonuç}

Araştırmada gebelerde üriner inkontinans probleminin yaygın olduğu, sosyodemografik ve obstetrik özellikler ile alt üriner yol semptomları arasında önemli ilişki olduğu ve gebelikte üriner inkontinans arttıkça yaşam kalitesinin azaldığg saptanmıştır.

Araştırmadan elde edilen sonuçlara göre gebelikte üriner inkontinansı azaltmak için şu önerilerde bulunulabilir;

- Başta hemşireler olmak üzere sağlık çalışanlarında gebelikte üriner inkontinans ile ilgili farkındalık oluşturulması,

- Hemşirelerin üriner inkontinansı olan gebelere risk faktörlerini önlemeye yönelik eğitim vermesi (sigaradan, kafein içeren içeceklerden uzak durmaları, fazla kilo almaktan kaçınmaları vb.) 
- Şiddetli üriner inkontinans problemi olan gebelerin sağlık kuruluşlarına başvurmalarının sağlanması.

\section{Araştırmanın Etik Boyutu}

Araştırmanın uygulanabilmesi için ilgili üniversitenin Sağlık Bilimleri Girişimsel Olmayan Klinik Araştırmalar Etik Kurulu'ndan onay (2017/13-20) ve araştırmanın yürütüldüğü kurumdan yazılı izin alınmıştır.

\section{Bilgilendirilmiş Onam}

Araştırmaya katılan tüm gebelere bilgilendirilmiş onam formu imzatılmıştır.

\section{Yazar Katkıları}

Araştırmanın fikri, veri toplama süreci, analiz ve yorumu, literatür taraması, makale yazımı C.G.İ. tarafından yapılmışken, sonuçlara ulaşılmasını sağlayacak yöntemin tasarlaması ve planlanması, çalışmanın yürütülmesini organize etmek, ilerlemesini gözetmek ve sorumluluğunu almak, çalışmanın teslim edilmesinden önce, dil ve yazınsal düzeltmelerden bağımsız olarak, bilimsel anlamda çalışmanın yeniden değerlendirmesi S.T.T. tarafından yapılmıştır.

\section{Çıkar Çatışması Beyanı}

Yazarların herhangi bir çıkara dayalı ilişkisi yoktur.

\section{Araştırma Desteği}

Çalışmayı maddi olarak destekleyen kişi/kuruluş yoktur.

\section{Beyanlar}

3rd International Health Sciences Conference (IHSC 2019)'da sözel bildiri olarak sunulmuştur.

\section{Kaynaklar}

1. Özcan H. ve Beji NK. Üriner inkontinanslı hastaların değerlendirilmesinde kullanılan önemli bir parameter: Yaşam kalitesi. Göztepe Tip Dergisi. 2014; 29(4): 236-238.

2. Milsom I, Coyne KS, Nicholson S, Kvasz M, Chen CI, Wein AJ. Global prevalence and economic burden of urgency urinary incontinence: a systematic review. Eur Urol. 2014;65(1):79-95. doi: 10.1016/j.eururo.2013.08.031

3. Kumari S, Jain V, Mandal AK, Singh A. Behavioral therapy for urinary incontinence in India. Int $J$ Gynaecol Obstet. 2008;103(2):125-130. doi: 10.1016/j.ijgo.2008.06.019

4. Xie X, Chen Y, Khan A, Long T, Li S, Xie M. Risk factors for urinary incontinence in Chinese women: A Cross-sectional Survey. Female Pelvic Med Reconstr Surg. In press. 2020 Apr 9. doi: 10.1097/SPV.0000000000000871
5. Mostafaei H, Ghojazadeh M, Onur R, et.al. Prevalence of female urinary incontinence in the developing world: A systematic review and meta-analysis-A Report from the Developing World Committee of the International Continence Society and Iranian Research Center for Evidence Based Medicine. Neurourol Urodyn. In press. 2020 Apr 3. doi: 10.1002/nau.24342

6. Akgün G, Süt N, Kaplan PB. Kırk Yaş üzeri kadınlarda üriner inkontinans sıklığı ve yaşam kalitesi üzerine etkileri. Türkiye Klinikleri Jinekoloji Obstetrik Dergisi. 2010; 20(6):378-386.

7. Çiftçi Ö, Günay O. Kayseri eğitim ve araştırma hastanesi jinekoloji polikliniğine başvuran kadınlarda üriner inkontinans sıklığı ve etkileyen faktörler. Erciyes Tip Dergisi. 2011;33(4):301-308.

8. Özdemir E, Özerdoğan N, Ünsal A. Ankara Gülveren Sağlık Ocağı Bölgesi'nde 20 yaş üzeri evli kadınlarda üriner inkontinans, cinsel disfonksiyon ve yaşam kalitesi. Türkiye Klinikleri Jinekoloji ve Obstetri Dergisi. 2011;21(4):266-276.

9. Yılmaz E, Muslu A, Özcan E. Üriner inkontinanslı kadınlarda yaşam kalitesi. Erciyes Üniversitesi Sağlık Bilimleri Fakültesi Dergisi. 2014;2(2):1-14.

10. Liu B, Wang L, Huang SS, Wu Q, Wu DL. Prevalence and risk factors of urinary incontinence among Chinese women in Shanghai. International Journal Of Clinical And Experimental Medicine. 2014;7(3):686. https://www.ncbi.nlm.nih.gov/pmc/articles/PMC3992409/

11. Başak T, Kok G, Güvenç G. Prevalence, risk factors and quality of life in Turkish women with urinary incontinence: A synthesis of the literature. Int Nurs Rev. 2013;60(4): 448-460. doi: 10.1111/inr.12048

12. Dönmez S, Kavlak O. Gebelikte pelvik taban kas egzersizi. Balıkesir Sağllk Bilimler Dergisi. 2014;3(1):45-49.

13. Abdullah B, Ayub SH, Zahid AZ, Noorneza AR, İsa RM, Ng PY. Urinary incontinence in primigravida: The neglected pregnancy predicament. Eur J Obstet Gynecol Reprod Biol. 2016;198(p1-180):110-115. doi:10.1016/j.ejogrb.2016.01.006

14. Nigam A, Ahmad A, Gaur D, Elahi AA, Batra S. Prevalence and risk factors for urinary incontinence in pregnant women during late third trimester. International Journal of Reproduction, Contraception, Obstetrics and Gynecology. 2016; 5(7): 2187-2191. doi: 10.18203/23201770.ijrcog20162090

15. Sangsawang B, Sangsawang N. Stress urinary incontinence in pregnant women: A review of prevalence, path ophysiology, and treatment. Int Urogynecol J. 2013; 24(6): 901-912. doi: 10.1007/s00192-013-2061-7

16. Kocaöz S, Talas MS, Atabekoğlu CS. Urinary incontinence in pregnant women and their quality of life. J Clin Nurs. 2010;19(23-24):3314-3323. doi:10.1111/j.13652702.2010.03421.x

17. Dağdeviren H, Kaya C, Cengiz H, Erdoğan VŞ, Helvacioğlu Ç, Bilecan MS. Urinary incontinence in pregnant women and its relation with quality of life. Istanbul Tup Dergisi. 2018;19(1): 43-46.

18. Karakuş A, Yanıkkerem E. Postpartum dönemde inkontinans ve yaşam kalitesi: Son 10 yıllık çalışmalar. Celal Bayar Üniversitesi Sağlık Bilimleri Enstitüsü Dergisi. 2015;2(3):5459.

19. Aydin A, Kocaöz S, Kara P. Prevalence of lower urinary tract symptoms in pregnant adolescents and the influencing factors. Journal of Pediatric and Adolescent Gynecology. 2019; 33(2):160-166 doi:10.1016/j.jpag.2019.10.007

20. Jackson S, Donovan J, Brookes S, Eckford S, Swithinbank L, Abrams P. The Bristol female lower urinary tract symptoms questionnaire: Development and psychometric testing. $\mathrm{Br} J$ Urol. 1996;77(6):805-812. doi:10.1046/j.1464410X.1996.00186.x

21. Güngör F, Yalçın Ö. Stres üriner inkontinans olgularında tension-free vaginal tape ve tension free vaginal tape obturator operasyonlarının klinik ve ürodinamik sonuçlarının karşılaştırılması. [Uzmanlık Tezi]. İstanbul, Türkiye: İstanbul Üniversitesi Tıp Fakültesi, Kadın Hastalıkları ve Doğum Anablilim Dalı; 2005.

22. Wagner TH, Patrick DL, Bavendam TG, Martin ML, Buesching DP. Quality of life of persons with urinary incontinence: Development of a new measure. Urology.1996;47(1):67-71. doi:10.1016/S0090-4295(99)80384- 
23. Patrick DL, Martin ML, Bushnell DM, Yalcin I, Wagner TH, Buesching DP. Quality of life of women with urinary incontinence: Further development of the incontinence quality of life instrument (I-QOL). Urology. 1999; 53(1): 71-76. doi:10.1016/S0090-4295(98)00454-3

24. Eyigor S, Karapolat H, Akkoç Y, Yeşil H, Ekmekci O. Quality of life in patients with multiple sclerosis and urinary disorders: Reliability and validity of Turkish-language version of Incontinence Quality of Life Scale. J Rehabil Res Dev. 2010; 47(1):67-71. doi: 10.1682/jrrd.2009.08.0132

25. Oliveiraa, C, Selemeb M, Cansic $\mathrm{P}$, Consentinoc RF, Kumakurac FY, Moreirac G, Berghmans B. Urinary incontinence in pregnant women and its relation with sociodemographic variables and quality of life. Rev Assoc Med Bras, 2013;59(5):460-466. doi: 10.1016/j.ramb.2013.08.002

26. Demircan N, Özmen Ü, Köktürk F, Küçük H, Ata S, Harma M, Arıkan III. What are the probable predictors of urinary incontinence during pregnancy? PeerJ. 2016; 4(2283): 1-19. doi: $10.7717 /$ peerj. 2283

27. Dinç A. Prevalence of urinary incontinence during pregnancy and associated risk factors. Low Urin Tract Symptoms. 2018;10(3):303-307. doi: 10.1111/luts.12182

28. Kök G, Seven M, Guvenç G, Akyuz A. Urinary incontinence in pregnant women: Prevalence, associated factors, and its eff ects on health-related quality of life. J Wound Ostomy Continence Nurs. $\quad$ 2016; 43(5): 511-516. doi:10.1097/WON.0000000000000262

29. Martin's G, Soler ZASG, Cordeiro JA, Amaro JL, Moore KN. Prevalence and risk factors for urinary incontinence in healthy pregnant Brazilian women. International Urogynecology Journal. 2010; 21: 1271-1277.

30. Leroy SL, Lúcio A, Lopes MH. Risk factors for postpartum urinary incontinence. Rev Esc Enferm USP. 2016; 50(2):200207. doi: 10.1590/S0080-623420160000200004

31. Liang CC, Chang SD, Lin SJ, Lin YJ. Lower urinary tract symptoms in primiparous women before and during pregnancy. Arch Gynecol Obstet, 2012;285(5):1205-1210. doi: 10.1007/s00404-011-2124-2

32. Altınboğa O, Gültekin Bİ, Taner CE. Son üç y1l içinde doğum yapmış kadınlarda stres inkontinans: Parite ve doğum şeklinin etkisi. Bozok Tip Dergisi. 2016; 6(4): 1-7.

33. Demirci N, Aba YA, Süzer F, Karadağ F, Ataman H. 18 yaș üstü kadınlarda üriner inkontinans ve yaşam kalitesine etkileri. Firat Sağlık Hizmetleri Dergisi. 2012;7(19): 23-37.

34. Bekele A, Adefris M, Demeke S. Urinary incontinence among pregnant women, following antenatal care at University of Gondar Hospital, North West Ethiopia. BMC Pregnancy and Childbirth, 2016;16(1):1-6. doi:10.1186/s12884-016-1126-2

35. Brown SJ, Donath S, MacArthur C, McDonald EA, Krastev $\mathrm{AH}$. Urinary incontinence in nulliparous women before and during pregnancy: Prevalence, incidence, and associated risk factors. Int Urogynecol J. 2010;21(2):193-202. doi:10.1007/s00192-009-1011-x

36. Bilgili N, Akın B, Ege E, Ayaz S. Kadınlarda üriner inkontinans sıklı̆̆ı ve etkileyen risk faktörleri. Türkiye Klinikleri Tip Bilimleri Dergisi. 2008; 28(4): 487-493.

37. Baydock SA, Flood C, Schulz JA, Macdonald D, Esau D, Jones $\mathrm{S}$, Hiltz CB. Prevalence and risk factors for urinary and fecal incontinence four months after vaginal delivery. $J$ Obstet Gynaecol Can. 2009;31(1):36-41. doi:10.1016/s17012163(16)34051-8

38. Kaşıkçı M, Kılıç D, Avşar G, Şirin M. Prevalence of urinary incontinence in older Turkish women, risk factors, and effect on activities of daily living. Arch Gerontol Geriatr. 2015;61(2): 217-223. doi: 10.1016/j.archger.2015.06.008

39. Süt HK. Gebelik ve doğumun pelvik taban yetersizlikleri üzerine etkisi: önlenmesi ve korunmada hemşirenin rolü. Gümüşhane Üniversitesi Sağllk Bilimleri Dergisi. 2015; 4(2):292-304

40. Barbosa L, Boaviagem A, Moretti E, Lemos A. Multiparity, age and overweight/obesity as risk factors for urinary incontinence in pregnancy: A systematic review and metaanalysis. Int Urogynecol J. 2018;29(10):1413-1427. doi: 10.1007/s00192-018-3656-9

41. Oh SJ, Ku JH. Comparison of three disease-specific quality-oflife questionnaires (Bristol Female Lower Urinary Tract Symptoms, Incontinence Quality of Life and King's Health Questionnaire) in women with stress urinary incontinence.
Scand J Urol Nephrol. 2007; 41(1):66-71. doi:10.1080/00365590600917487 